\title{
ALASAN DAN HAMBATAN PENYAJIAN BUAH LOKAL DALAM OPERASIONAL HOTEL BERBINTANG DI SANUR
}

\author{
I Gusti Agung Diah Adelianie \\ Email: diahadelianie@gmail.com
}

\begin{abstract}
Indonesian tourism development is strongly supported by a wide range of sectors one of which being the agricultural as a supplier of local fruits which become tourist consumption processed into foods and beverages that have high sales value. This article discusses the dominant type of local fruits served in operations of five-star hotels in Sanur tourism area, the reason for the hotel to serve local fruits, and the obstacles experienced in serving them. The study used mix marketing theory and the theory of consumer decision-making attitude. The study was conducted by purposive sampling method with the study sites of seven star hotels in Sanur. Data were collected through observation, interviews, and by distributing 80 questionnaires filled out by the hotels. The study reveals that the dominant fruits served in hotel operations are fruits that did not depend on the season and are selected based on factors including of quality, continuity, price, serving variation, and policy where the dominant factor of this study was that of quality. This study concludes that there is a need for the cooperation between farmers, suppliers, hotels and the government in maximizing the absorption of local fruits at five-star hotels in Sanur.
\end{abstract}

Keywords: local fruits, serving local fruits, Sanur tourism area, non-seasanol fruit, fruit protection regulation.

\section{Pendahuluan}

Industri pariwisata adalah industri yang mendapat dukungan dari berbagai sektor, salah satu pendukungnya adalah sektor pertanian. Sektor ini menyumbangkan produksi hasil pertanian yang dapat diserap oleh industri pariwisata salah satunya buah lokal. Indonesia juga memiliki berbagai jenis buah lokal yang tumbuh subur karena wilayah Indonesia merupakan wilayah tropis yang berada di garis khatulistiwa sehingga memungkinkan berbagai macam pohon buah tumbuh subur. Menurut Antara dan Yono Wirawan (2013:17), buah-buahan merupakan salah satu jenis tanaman holtikultura yang bersifat menahun yang lebih dikenal sebagai sumber vitamin dan mineral yang sangat diperlukan oleh tubuh manusia. Pemanfaatan buah 
lokal dengan promosi pengenalan buah lokal dilakukan pemerintah yang bekerja sama dengan masyarakat (petani buah) dan pihak swasta.

Terserapnya buah lokal di industri pariwisata dianggap memberi dampak yang sangat besar. Industri pariwisata memberikan peluang bagi petani buah untuk menghasilkan buah sebagai konsumsi wisatawan yang secara tidak lagsung dapat meningkatkan taraf hidup petani, mengurangi biaya buah import dan menumbuhkan rasa cinta buah lokal.

Hotel pada umumnya menggunakan buah lokal karena buah lokal lebih segar dibandingkan buah impor, buah lokal tidak melewati perjalanan yang terlalu panjang dan buah lokal dipetik dari kebun dalam kondisi yang relatif matang dan langsung dipasarkan yang berbeda dengan buah impor melalui proses pengiriman yang panjang serta pengemasan yang menggunakan pengawet sehingga membuat vitamin dan nutrisi yang terkandung berkurang. Adanya alur distribusi yang panjang juga berdampak pada harga buah impor lebih mahal dibandingkan dengan buah lokal, karena hotel menyajikan buah setiap hari akan berdampak pada pengeluaran/ cost pada hotel tersebut. Penyajian buah sehari-hari juga dapat memperkenalkan keunikan buah lokal yang dimiliki Indonesia pada wisatawan dan menumbuhkan rasa cinta terhadap produk lokal. Penyajian buah lokal pada hotel berbintang di Kawasan Sanur menyajikan buah lokal yang tidak bergantung pada musim untuk memudahkan penyajian dalam operasional sehari-hari.

Kontribusi buah lokal sebagai konsumsi wisatawan dengan cara penyajian buah lokal fresh dalam bentuk fruit basket dan welcome drink saat tamu check in, mix juice, fruit cocktail dan fresh blended juice, hidangan pencuci mulut (dessert), garnish makanan dan fruit cutting untuk buffet. Upaya promosi dan pengenalan buah lokal dilakukan dengan adanya peran serta staf pada hotel di Kawasan Sanur dalam memberikan education kepada tamu tentang nama buah, manfaat dan keunikan buah lokal, selain itu adanya memo dari GRO (Guest Relation Officer) juga sangat membantu memberikan penjelasan kepada tamu.

Keberadaan pasar memungkinkan terserapnya buah lokal pada destinasi pariwisata karena memiliki banyak hotel dan dikunjungi oleh banyak wisatawan. Kenyataan ini merupakan salah satu target yang bisa disasar untuk pemasaran hasil produksi dari petani. Permasalahan yang terjadi kebanyakan membanjiri pasar lokal pada saat panen raya di mana eksistensi buah lokal di industri pariwisata memiliki pertimbangan dari pendapat pelaku industri pariwisata untuk dipergunakan dalam operational dikarenakan kualitas yang kurang memadai, ketiadaan kontinuitas dan volume yang tidak mencukupi. Upaya mengoptimalkan penggunaan buah lokal dalam industri pariwisata dilakukan dengan cara menggunakan buah lokal yang tidak musiman sehingga hotel bisa mendapatkannya sepanjang tahun. 
Permasalahan yang terjadi sebaiknya ada tindak lanjut dari pemerintah dalam hal peminjaman modal pengembangan pertanian buah lokal dan diadakan nya pelatihan dalam pemberian penyuluhan. Pelatihan bertujuan untuk meningkatkan kuantiti buah lokal masa panen serta memberikan solusi dalam setiap permasalahan yang dihadapi petani lokal. Kegiatan pelatihan bisa menjawab permasalahan yang dihadapi petani, diharapkan kedepannya dengan adanya buah lokal dapat mempromosikan kekayaan budaya kuliner lokal kepada para wisatawan.

Upaya peminjaman modal untuk petani buah dibantu dengan ada integrasi komplementari antara pariwisata dan pertanian melalui data base yang akurat dan komprehensif tentang potensi produk pertanian dan penyerapan produk pertanian lokal di industri pariwisata Bali. Sumber data base membantu pemerintah memetakan kebutuhan produk pertanian, pihak hotel dan restoran di Bali. Pemetaan itu diharapkan mempunyai data pasti sehingga ada link and match antara apa yang dibutuhkan industri pariwisata dan produk pertanian yang akan dikembangkan.

Permasalahan yang terjadi adalah pemanfaatan buah lokal di industri pariwisata sudah berlangsung baik namun belum secara maksimal, hal ini dikarenakan sifat buah lokal yang kebanyakan musiman. Dalam situasi demikian pihak hotel kesulitan menyajikan buah yang sama setiap harinya. Ketersedian buah lokal yang pada umumnya bersifat musiman akan menjadi bumerang saat pihak hotel berupaya memperkenalkan produk buah lokal yang dimiliki di Indonesia.

Dari identifikasi masalah di atas, maka penelitian ini membahas tiga hal yaitu (1) Jenis buah lokal apa saja yang dominan disajikan pada operasional hotel berbintang kawasan pariwisata Sanur?; (2) Faktor-faktor apa saja yang menjadi alasan pihak hotel dalam penyajian buah lokal di hotel berbintang kawasan pariwisata Sanur?; (3) Apa saja hambatan-hambatan yang dialami pihak hotel dalam penyajian buah lokal dalam operasional pada hotel berbintang kawasan pariwisata Sanur?

\section{Teori dan Metode}

Mengingat alur distribusi buah lokal dari tangan petani hingga dapat disajikan pada hotel berbintang lima di kawasan pariwisata Sanur tidak lepas dengan sistem pemasaran, maka teori bauran pemasaran digunakan dalam penelitian ini. Teori Bauran Pemasaran menurut Assauri (2009:5) memiliki sistem pemasaran sebagai usaha yang menyediakan dan menyampaikan barang dan jasa yang tepat kepada orang-orang yang tepat pada tempat dan waktu serta harga yang tepatdengan promosi dan komunikasi yang tepat. Adapun elemen $4 \mathrm{P}$ (product, price, place, promotion) Bauran Pemasaran terdiri dari kombinasi variabel-variabel pemasaran yang merupakan faktor internal yang dimiliki oleh hotel berbintang di antaranya : 


\section{a. Produk}

Pihak supplier buah berusaha menawarkan kualitas produksi buah (product) yang akan menyebabkan pasar sasaran menyukainya bahkan bersedia membayar tinggi. Untuk mengoptimalkan penyerapan buah lokal pada hotel berbintang diperlukan kerjasama strategi dengan petani buah dalam memasarkan produk buah lokal dengan mengadakan sortasi setelah panen buah lokal, dalam sortasi ini sangat membantu mengelompokkan ukuran buah dan mengelompokkan buah mana yang dapat di ekspor dan buah yang dapat dikonsumsi dalam negeri. Setelah melakukan proses sortasi dilakukan proses pengemasan buah terhadap kerusakan akibat cuaca dan kotoran, buah-buahan yang melewati sortasi dikemas sesuai dengan ukuran buah. Produk buah lokal yang dalam keadaan segar dan tidak lecet dapat membuat buah lokal mempunyai nilai jual tinggi sehingga buah yang segar dapat menarik minat pihak hotel berbintang untuk membeli. Atribut produk yang memenuhi standar hotel akan memudahkan hotel untuk mengolah buah lokal untuk dapat disajikan kepada wisatawan setiap harinya

\section{b. Harga}

Harga (price) merupakan elemen dalam perusahaan yang dapat menghasilkan pemasukan dan biaya, sehingga harga dapat berubah secara fleksibel agar mengenai sasaran sehinggga menghasilkan pemasukan. Harga juga sangat berpengaruh pada ketersediaan buah lokal. Saat buah lokal tidak pada musimnya atau saat musim kemarau akan berdampak pada tinggi nya harga buah yang berbanding terbalik saat musim panen maka produksi buah yang melimpah membuat harga buah lokal di pasaran menjadi turun. Harga yang ditetapkan oleh supplier buah pada umumnya dengan menambahkan harga pokok buah yang dibeli dari penjual dan biaya distribusi buah, karena apabila buah yang dijual memiliki alur distribusi yang panjang maka akan ada penambahan biaya yang mempengaruhi nilai jual buah lokal.

\section{c. Tempat}

Banyaknya pedagang perantara membuat mata rantai tata niaga menjadi semakin panjang. Akibatnya tingkat harga yang diterima petani relatif sangat rendah dibanding dengan harga yang harus dibayar oleh konsumen. Dampak keterlambatan distribusi buah lokal dari tempat (place) produsen ke konsumen membuat fenomena peredaran buah impor menjadi menjamur di pasaran, fenomena buah impor dengan harga murah, supply buah yang melimpah, warna dan penampilan buah impor yang menarik sehingga buah impor tidak kesulitan untuk memasarkan.

\section{d. Promosi}

Kegiatan promosi (promotion) yang dilakukan untuk memperkenalkan 
buah lokal telah dilakukan oleh pihak pemerintah yang bekerja sama dengan pihak swasta dan petani buah. Kegiatan promosi dalam hotel berbintang di Kawasan Sanur dengan menambahkan sajian buah lokal dalam operasional hotel sehingga kemungkinan besar terserap banyak buah lokal pada operasional hotel dan penambahan penyajian buah lokal pada event MICE yang ada pada hotel tersebut.

Konsumen akan melewati beberapa tahapan $4 \mathrm{P}$ dalam proses pengambilan keputusan dalam melakukan pembelian suatu produk. Prilaku konsumen meliputi beberapa jenis diantaranya keputusan yang satu mempengaruhi keputusan yang lain. Tindakannya misalnya keputusan untuk membeli suatu produk atau tidak, apabila membeli suatu produk maka akan mengarah pada merek produk tersebut, bila sudah memutuskan membeli maka pembelian akan dihadapkan pada pilihan saluran untuk membeli kemudian menyangkut pembayaran sehingga keputusan bisa berpengaruh pada jenis keputusan lainnya (Suprapti, 2010;264).

Artikel ini menggunakan metode kualitatif dengan mengambil lokasi di hotel berbintang klasifikasi hotel berbintang 2 hingga hotel berbintang 5 yang berada kawasan Sanur. Hotel tersebut yaitu Inna Grand Bali Beach, Prama Sanur Beach, Sanur Paradise Plaza Hotel, Mercure Hotel, Segara Village Hotel, Griya Santrian, dan Tandjung Sari. Pengumpulan data dilakukan menggunakan teknik observasi, wawancara, dokumentasi, kuisioner dengan total 80 kuesioner. Penentuan informan dilakukan dengan purposive sampling dengan wawancara langsung kepada food and beverage manager, purchasing manager, store, receiving, banquet manager dan supplier buah.

\section{Pembahasan}

Pengisian kuesioner dilakukan oleh 80 responden yang tersebar pada tujuh hotel berbintang yang menjadi objek penelitian di kawasan pariwisata Sanur. Penelitian ini menunjukkan lebih dari 50\% responden adalah laki-laki yang sebagian besar karyawan hotel dengan masa bekerja 5-20 tahun telah ada pada posisi Manager atau bidang yang berpotensi untuk mengambil keputusan dalam operasional hotel. Jumlah responden dengan latar belakang tingkat pendidikan Diploma mendominasi yaitu 55\% dengan jumlah responden 44 orang.

Hasil penelitian pada tujuh hotel berbintang di kawasan Sanur bahwa buah lokal terserap maksimal pada industri pariwisata khususnya hotel berbintang di Sanur dengan menyajikan buah lokal pada operasional seharihari dalam bentuk sajian makanan dan minuman untuk wisatawan.

\subsection{Buah Lokal yang Dominan Disajikan}

Variasi buah lokal yang dipergunakan adalah buah lokal yang tidak bergantung pada musim seperti pisang, semangka, melon, nangka, nanas, 
jeruk, mangga dan papaya. Buah lokal musiman seperti salak, markisa, manggis, rambutan dan buah naga disajikan saat kegiatan tertentu seperti display seasional fruit saat breakfast, special drink dan sesuai permintaan tamu selama buah tersebut ada pada saat musimnya.

Penyajian buah lokal dalam operasional sangat membantu promosi kepada wisatawan yang diolah menjadi produk makanan dan minuman di antaranya:

\subsubsection{Appetizer dan dessert}

Appetizer atau makanan pembuka terdiri dari makanan pembuka yang disajikan untuk menggugah selera makan. Penyajian buah lokal untuk jenis appetizer terdapat pada menu Cold appetizer yang banyak sekali dijumpai di Eropa, jenis makanan ini disajikan pada kondisi dingin atau suhu ruangan. Pengolahan buah lokal untuk sajian cold appetizer pada umumnya terdapat pada fruit cocktail, fruit juice dan fruit slice (Riyadi dkk, 2011:22). Contoh cold appetizer di Griya Santrian Hotel.

Makanan yang tergolong cold appetizer (umpan tengkak dinging) terdapat pada menu lunch maupun dinner. Selain itu buah-buahan merupakan makanan penutup yang paling populer baik di Asia maupun Eropa. Penyajian buah lokal untuk appetizer maupun dessert disajikan pada buffet breakfast. Menurut Bapak Sudarnata dari Prama Sanur Beach “...buah lokal banyak disajikan saat breakfast karena pada umumnya hotel menawarkan harga kamar include breakfast yang mengharuskan pihak FB menyediakan pasokan buah yang lebih banyak dibandingkan dengan regular buffet event" (Wawancara, tanggal 5 Januari 2015).

Pihak hotel yang memiliki harga kamar include breakfast dapat memperkirakan jumlah order buah lokal dari room forecast report sehingga banyaknya buah yang diorder dapat diperkirakan sehari sebelumnya. Penyajian buah lokal pada saat breakfast tidak dapat diporsikan karena sajian buah lokal ada pada buffet yang dapat dinikmati sesuai kebutuhan wisatawan. Semakin banyak room include breakfast maka semakin banyak buah yang akan diserap oleh pihak hotel.

\subsubsection{Fruit Basket}

Penyajian buah lokal dalam bentuk fruit basket paling banyak disajikan pada hotel berbintang di Kawasan Pariwisata Sanur. Fruit basket biasa disajikan pada tamu yang check in, tamu VIP, tamu VVIP dan terkadang beberapa hotel memiliki aturan dalam menyajikan fruit basket. Menurut Bapak Sudinata dari Prama Sanur Beach menjelaskan ...”penyajian buah lokal untuk fruit basket dipilihkan dari buah lokal yang sesuai musim pada saat itu yang disajikan dengan menyelipkan welcome card saat delivery fruit basket. Team Food and Beverage akan menyajikan fruit basket untuk kamar Expected 
Arrival dengan melampirkan request dari Guest Relation Officer (GRO) dimana fruit basket yang disajikan berbeda sesuai dengan tipe kamar" (Wawancara, tanggal 5 Januari 2015). Contoh fruit basket di Griya Santrian Hotel seperti Foto 1.

Penyajian fruit basket dengan menggunakan buah lokal secara tidak langsung dapat memperkenalkan hasil produksi Indonesia sebagai konsumsi wisatawan. Terserapnya buah lokal diharapkan paling banyak terserap pada sektor pariwisata yang sedang berkembang seperti saat ini. Buah lokal yang dimiliki Indonesia memiliki tampilan yang unik yang dapat disajikan dengan menggabungkan beberapa buah lokal dalam satu piring sajian atau menggunakan buah yang sama dalam satu piring sajian. Selain dari nilai estetika, harga buah lokal juga menjadi pertimbangan cost saat penyajian fruit basket, hal ini disebabkan akan ada alokasi potongan biaya harga kamar untuk Foto 1. Fruit basket. penyajian fruit basket.

\subsubsection{Welcome drink dan juices}

Penyajian buah lokal tidak hanya disajikan dalam bentuk fresh fruit tetapi disajikan juga dalam bentuk welcome drink dengan mengolah buah lokal yang dicampurkan dengan minuman lain. Welcome drink disajikan pada saat tamu check in oleh Reception. Olahan buah lokal lainnya disajikan dalam bentuk juice seperti fresh juice dan healty juice dimana komposisi lebih banyak menggunakan buah lokal dibandingkan dengan sirup buah.

\subsubsection{Fruit Carving}

Fruit curving atau seni mengukir buah biasanya menggunakan buah lokal seperti papaya, semangka, nanas dan melon. Penggunaan fruit carving tidak sebanyak menggunakan buah lokal dalam sajian breakfast. Fruit carving biasanya digunakan untuk dekorasi pada buffet saat ada regular event di hotel.

Penyajian buah lokal dalam operasional hotel berbintang di Kawasan Sanur cukup menjanjikan dibandingkan buah impor. Pemanfaatan buah impor pada 
umumnya lebih sedikit persentasenya dibandingkan dengan buah lokal.

Penyajian buah impor saat special event biasanya berdasarkan request. Menurut IB Agung yang merupakan salah satu sous chef Griya Santrian “ buah impor disajikan karena ada request dari tamu dan akan dikenakan biaya tambahan dari harga normal. Penyajian buah impor yang terjadi di hotel dengan menggunakan buah anggur, kiwi, peach, raspberry dan honeydew" (Wawancara, tanggal 10 Januari 2015).

Pernyataan tersebut menjelaskan bahwa permintaan buah impor lebih sedikit dibandingkan buah lokal. Hal ini tentunya memberikan harapan di masa yang akan datang akan terserapnya buah lokal dengan baik dalam industri pariwisata. Kerjasama antara pihak hotel, supplier, petani buah dan pemerintah diharapkan mendorong promosi buah lokal sebagai konsumsi ekspor Indonesia. Hal tersebut didukung oleh peran serta pemerintah dalam membuat Peraturan Daerah Provinsi Bali mengenai buah lokal.

\subsection{Faktor-faktor Alasan Hotel Menyajikan Buah Lokal}

Penyajian buah lokal pada hotel berbintang dipengaruhi oleh beberapa faktor dimana faktor-faktor dapat dikatagorikan kedalam lima faktor diantaranya kualitas, kontinuitas, harga, variasi penyajian dan kebijakan. Faktor-faktor yang menjadi alasan pihak hotel dalam menyajikan buah lokal dapat diuraikan sebagai berikut :

\subsubsection{Kualitas}

Kualitas buah lokal dapat dilihat dari rasa dan fisik buah yang terkadung dalam buah lokal. Penelitian ini membahas kualitas buah lokal dari segi rasa, tampilan buah, ukuran buah, warna buah dan kebersihan buah.

Tampilan buah lokal segar juga terdapat pada buffet breakfast, penyajian di meja buffet dipilih buah yang masih segar, bersih dan tidak lecet karena buah yang baik dapat menarik minat wisatawan untuk mencoba. Buah lokal dalam keadaan segar dan matang ditangan konsumen karena buah lokal yang dipanen pada saat kematangan buah sudah mencapai setengahnya dan saat mencapai ke tangan konsumen buah sudah mengalami kematangan yang sempurna. Sehingga tidak membutuhkan zat aditif atau pengawet untuk mengawetkan buah-buahan dan menjadikan buah tersebut manis. Contohnya, buah jeruk Kintamani memiliki rasa manis dan asam yang menyegarkan sedangkan buah jeruk impor memiliki rasa yang datar yang tidak menyegarkan (Foto 2).

Tampilan buah lokal jika dilihat dari segi fisik memang kurang menarik, namun dari segi rasa dan kandungan vitamin dari buah lokal sangat baik dibandingkan dengan buah impor. Selain tidak menggunakan bahan pengawet yang membahayakan, rasa buah lokal pun jadi lebih nikmat dan mengandung banyak vitamin dan mineral yang dibutuhkan oleh tubuh. 


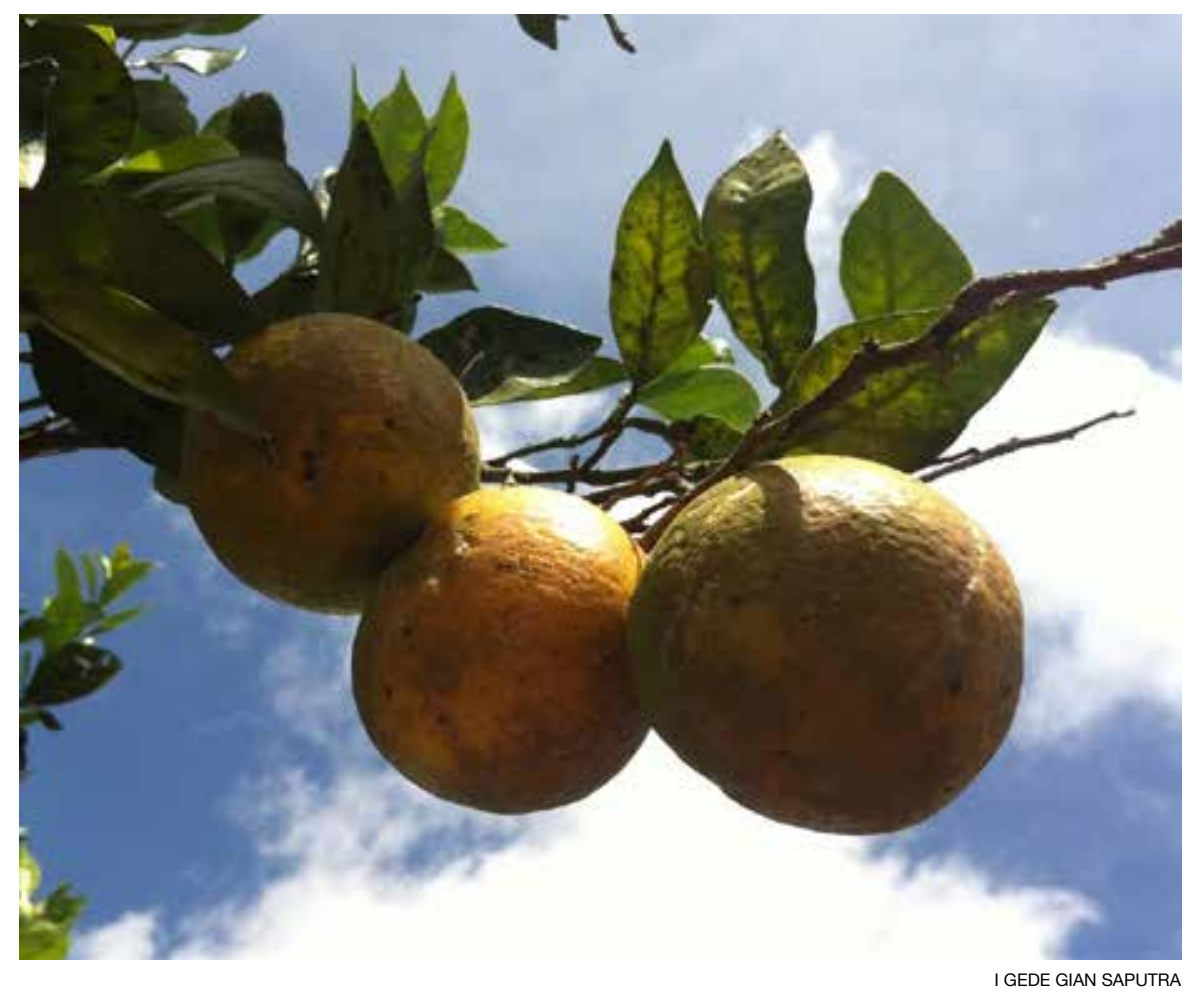

Foto 2: Jeruk Kintamani, buah local yang kembali populer.

Tampilan buah lokal yang bervariasi memiliki standarisasi buah yang dikonsumsi di hotel berbintang sesuai dengan kebutuhan operasional.

Ukuran buah lokal yang disajikan adalah Grade $A$ terdiri dari buah yang dengan ukuran besar dipergunakan pada industri pariwisata dan sebagian terdapat di supermarket (Wirawan dkk, 2014:22). Buah lokal dengan keadaan alami dan fresh jauh lebih baik untuk kesehatan dibandingkan buah impor yang memiliki warna yang menarik dengan banyak residu pestisida. Warna buah lokal yang alami dan segar menandakan buah tersebut tidak mengandung pengawet, karena pada umumnya buah impor memiliki pengawet yang membuat warna buah menjadi mengkilap dan tidak cepat busuk ketika melewati proses distribusi yang panjang sampai ke tangan pembeli.

Kebersihan sangat berpengaruh pada penyajian buah lokal, pada saat buah masuk ke hotel berbintang maka faktor kebersihan menjadi hal yang dapat dilihat secara fisik. Buah yang dalam keadaan bersih akan memudahkan dalam menyimpan. Buah yang diterima dalam keadaan lecet dan kotor dapat berdampak pada buah lain yang disimpan dalam wadah yang sama dan bisa mengakibatkan buah cepat busuk. Faktor kebersihan buah sangat penting dan tidak boleh disepelekan saat mengkonsumsi buah impor ataupun lokal, sehingga pencemaran bakteri jenis apapun bisa dicegah. 


\subsubsection{Kontinuitas}

Buah merupakan komoditas pertanian yang memiliki banyak manfaat dan sekaligus ancaman dalam penyediaannya. Buah lokal memiliki ancaman dari dua sisi yaitu ancaman yang berasal dari dalam negeri dan luar negeri. Ancaman yang berasal dari dalam negeri antara lain rendahnya pengetahuan berbasis pertanian di kalangan petani buah lokal secara umum, kurangnya penyediaan sarana dan prasarana pertanian buah mulai dari pra panen hingga pascapanen, kurangnya penyuluhan produk hortikultura dari pemerintah, berkurangnya lahan pertanian buah di Indonesia, perubahan iklim yang ekstrem, beralihnya fungsi lahan pertanian menjadi pemukiman akibat bertambahnya jumlah penduduk Indonesia, dan kurangnya pengawasan serta rendahnya peran pemerintah dalam melindungi produk buah lokal.

Ancaman dari dalam negeri membuat anggapan masyarakat bahwa dengan mengonsumsi atau membeli buah impor merupakan hal yang berkelas dan mampu dari status sosial. Selain itu, ancaman yang berasal dari luar negeri meliputi terbukanya perdagangan pasar internasional, tingginya mutu buah yang berasal dari luar negeri dengan penggunaan teknologi canggih dalam pengolahan buah impor dan ketersediaan produksi buah impor yang melimpah. Ancaman dari luar negeri dapat diminimalkan dengan mampu mengelola dan mempertahankan sumber daya alam produk buah-buahan lokal. Pengelolaan yang baik mampu menjadi modal dalam mempertahankan eksistensi buah lokal dari ancaman buah impor.

Kontinuitas buah lokal pada hotel berbintang di Kawasan Sanur dapat membantu penyerapan hasil pertanian buah yang dapat meningkatkan taraf hidup petani buah, memperkenalkan keanekaragaman buah yang dimiliki Indonesia yakni buah musiman dan buah tidak bermusim kepada wisatawan. Kontinuitas buah lokal dalam industri pariwisata tetap terpenuhi karena lebih dominannya penyajian buah lokal yang tidak bergantung pada musim.

\subsubsection{Harga}

Harga buah lokal jauh lebih murah dibandingkan buah impor, karena buah lokal dihasilkan di Indonesia sehingga tidak memerlukan biaya untuk distribusi yang panjang seperti buah impor. Harga buah lokal musiman sangat berpengaruh saat musimnya maka harga buah akan menurun dan apabila buah itu tidak pada musimnya maka harga nya dapat melonjak naik. Saat buah lokal menanjak naik membuka peluang masuknya buah impor ke industri karena buah impor yang ditawarkan lebih murah dan tidak bergantung pada musim. Harga buah lokal menjadi naik dikarenakan juga karena tingginya biaya produksi, lokasi kebun yang jauh dari pasar yang membuat biaya tansportasi turut membengkak dan tidak maksimalnya memperbaiki kualitas pasca panen karena petani mengkhawatirkan menambah biaya. Kondisi ini menyebabkan buah lokal sulit bersaing dengan buah impor. 
Penyajian buah lokal pada hotel berbintang di kawasan Sanur adalah buah lokal yang dominan tidak bergantung pada musim, buah lokal yang disajikan di hotel berbintang di kawasan Sanur memiliki harga yang telah disepakati pada perjanjian dengan pihak hotel yang lebih murah dibandingkan di pasaran karena pihak hotel biasanya menjalin kerjasama dengan supplier dari Bedugul atau pasar induk. Pada umumnya, pihak hotel akan mengadakan market survey untuk menentukan kerjasama dengan pihak supplier buah. Perjanjian yang dibuat akan disepakati dalam tempo waktu tertentu dengan item jenis buah sesuai permintaan pihak hotel, harga yang telah disepakati dan kesepakatan lain-lain dimana terkadang akan mengalami kenaikan dari harga perjanjian yang biasanya karena faktor cuaca dan hal lainnya dan kondisi pembayaran.

\subsubsection{Variasi Penyajian}

Buah lokal jauh lebih murah dibandingkan buah impor sehingga penyajian buah lokal dalam jumlah yang besar tidak mempengaruhi tingginya cost operasional hotel. Harga buah lokal di pasaran akan turun pada saat buah tersebut pada musimnya sehingga pihak hotel biasanya membuat menu dengan ingredient mendominasi buah lokal musiman. Sajian buah lokal sangat tergantung dari tampilan buah dan ukuran buah. Kedua elemen ini sangat berpengaruh pada penyajian buah lokal dalam operasional hotel berbintang. Hotel berbintang yang ada di Kawasan Sanur memiliki standar yang berbeda-beda dalam menyajikan fruit basket. Umumnya, fruit basket terdiri dari minimal tiga buah yang disajikan dalam tempat yang diselipkan bunga segar dan greeting card pada kamar yang check in pada saat itu. Alokasi biaya untuk seporsi fruit basket akan dibebankan ke harga kamar, adapun sajian fruit basket pada Hotel Segara Village.

Penyajian fruit basket salah satu kegiatan hotel dalam mempromosikan buah lokal. Fruit basket yang disajikan dimasing-masing kamar merupakan complimantary sehingga wisatawan dapat mencoba dengan gratis. Kegiatan operasional hotel dapat memperkenalkan buah lokal kepada wisatawan melalui buah lokal yang ada pada buffet display biasanya diberikan nama atau food tag untuk memperkenalkan nama buah serta staff hotel juga akan menginformasikan kepada tamu bagaimana cara menikmati buah lokal tersebut dan khasiat buah lokal.

\subsubsection{Kebijakan}

Adanya peraturan pemerintah dan kebijakan hotel tentang pemanfaatan buah lokal dalam sajian sehari-hari sangat membantu penyerapan buah lokal. Hotel berbintang di Kawasan Sanur beberapa telah mempunyai kebijakan hotel dalam pengolahan buah lokal seperti Prama Sanur Beach Hotel juga dalam Manajemen Aerowisata Hotel telah memiliki aturan dengan konsep 
authentic Indonesian hospitality hotel dengan memanfaatkan 100\% buah lokal dalam operasional hotel. Kebijakan ini diharapkan agar hotel dapat menyerap buah lokal, mengadakan promosi buah lokal untuk wisatawan yang menginap dan dapat membantu menekan cost operasional.

Program pemanfaatan buah lokal dalam penyajian sehari-hari juga mendorong adanya program sustainable development pada Mercure Hotel dengan memanfaatkan local product terdapat pada website dengan pencapaian penyajian produk lokal melebihi target yang disepakati oleh pihak Manajemen Accor. Hotel berbintang di kawasan Sanur memanfaatkan maksimal buah lokal dalam operasionalnya. Penyajian maksimal buah lokal dalam operasional selain mempunyai kebijakan yang dimiliki oleh hotel juga terdapat pada kriteria Tri Hita Karana mewajibkan hotel di Bali menggunakan buah lokal sebagai penerapan perlindungan buah lokal. Hal ini juga sebagai instrument penilaian pada Tri Hita Karana Awards.

\subsection{Hambatan Hotel dalam Penyajian Buah Lokal}

Penyerapan buah lokal pada operasional hotel berbintang sangat menguntungkan berbagai pihak darisegi ekonomi dan dapat mempromosikan produksi lokal kepada wisatawan sebagai olahan konsumsi. Pemanfaatan buah lokal juga menemui hambatan dalam penyajian operasional hotel berbintang dapat dijabarkan sebagai berikut :

\subsubsection{Pihak Hotel Berbintang}

Penyajian buah lokal pada hotel berbintang pada operasional sehari-hari dalam kuantitas yang cukup banyak. Penyerapan buah lokal pada hotel sangat menguntungkan petani buah dalam meningkatkan taraf perekonomian, hal ini kadang tidak berbarengan dengan peningkatan kualitas buah lokal yang dikirim ke hotel melalui supplier. Kegiatan sortasi yang belum maksimal mengakibatkan buah lokal yang dikirim ke hotel tidak dalam keadaan fresh dan terkadang ada yang bagian yang busuk karena sistem sortasi yang belum maksimal dan keadaan buah yang bebas dari ranting dan daun. Pihak hotel melalui receiving mengembalikan buah tersebut karena tidak sesuai dengan kesepakatan perjanjian, dalam hal seperti ini sangat diharapkan supplier yang lebih memperhatikan kualitas buah lokal yang sesuai dengan permintaan hotel. Hambatan lainnya saat pengiriman buah seperti semangka dan melon yang biasanya disajikan dalam buah potong dan dessert maka pihak receiving tidak dapat mengecek kualitas dalam semangka yang dikirim sehingga dalam beberapa kesempatan ada bagian yang lecet sehingga mengakibatkan kualitas semangka tersebut tidak dapat disajikan kepada wisatawan, dalam hal ini pihak hotel membeli buah semangka keluar hotel dalam keadaan urgent sehingga akan muncul tagihan secara cash yang merugikan pihak hotel dalam hal expenses bahan makanan. 
Expenses yang berupa tagihan kepada vendor akan dilunasi sebulan setelah transaksi sehingga pihak hotel dapat mengalokasikan pada bulan berikutnya sehingga cost atau pengeluaran langsung dapat diminimalkan.

\subsubsection{Pihak Supplier/vendor}

Hambatan yang dialami oleh pihak supplier/vendor dalam memenuhi permintaan buah lokal pada hotel berbintang di Kawasan Sanur meliputi pengiriman buah lokal oleh vendor merupakan hambatan dengan kurang baiknya kerjasama antara vendor dan hotel berbintang. Ada beberapa vendor yang melanggar perjanjian atau mangkir. Hal ini disebabkan oleh pelanggaran yang dilakukan vendor dalam hal pengiriman barang, jumlah yang diorder dan beberapa kesepakatan lainnya. Alasan vendor ini biasanya karena sistem pembayaran pelunasan tagihan yang melewati batas pembayaran oleh pihak hotel sehingga banyak vendor yang melakukan tindakan yang melanggar perjanjian.

Hambatan yang dialami oleh pihak hotel masih dapat diatasi dengan adanya komunikasi antara hotel dan pihak vendor. Penyerapan buah lokal yang berkualitas yang memenuhi standard dan melewati proses sortasi yang maksimal akan menghasilkan buah lokal dengan mutu yang tidak kalah bersaing dengan buah impor.

\section{Simpulan}

Sejak berkembangnya kepariwisataan di Bali, buah lokal tidak saja menjadi konsumsi masyarakat tetapi juga wisatawan melalui sajian di hotelhotel dan restoran. Industri pariwisata lebih banyak menyerap buah lokal dalam operasional hotel. Penyajian buah lokal yang lebih dominan terkadang mengalami kendala saat buah yang diproduksi menurun dan permintaan hotel meningkat sehingga mereka lebih cenderung menggunakan buah yang tidak bergantung pada musim. Untuk buah musiman food and beverages department biasanya akan membuat stand seasional fruit pada buffet untuk memperkenalkan buah lokal yang hanya pada musim tersebut diproduksi.

Artikel ini menyimpulkan bahwa penyajian buah lokal pada hotel berbintang di kawasan pariwisata Sanur menyajikan jenis buah lokal yang tidak bergantung pada musim menjadi komoditas buah yang paling banyak dipergunakan dalam operasional hotel berbintang. Faktor yang menjadi alasan pihak hotel dalam menyajikan buah lokal dalam operasional mereka di antaranya kualitas, kontinuitas, harga, variasi penyajian, dan kebijakan. Hambatan yang dialami selama penyajian buah lokal dari pihak hotel dan pihak vendor. Berdasarkan temuan penelitian, beberapa rekomendasi dapat disarankan pada artikel ini diantaranya penyerapan buah lokal secara maksimal pada hotel berbintang disajikan dalam operasional sehari-hari. 
Untuk menjaga kualitas buah yg diterima maka Hotel berbintang di kawasan Sanur menerapkan quality control saat menerima buah dari pihak supplier oleh pihak receiver (penerima). Petugas penerima harus memiliki dokumen Standar Spesifikasi untuk memastikan bahwa produk yang diterima dari segi kualitas, jenis, bentuk, ukuran telah benar. Mereka juga harus mempunyai lembaran surat pesanan (purchase order) untuk membandingkan kuantitas, kualitas, dan harga yang telah disepakati. Dengan demikian proses penerimaan berarti, proses kegiatan penerimaan bahan mentah, setengah jadi atau barang jadi, dari supplier (vendor) untuk pemenuhan kebutuhan restoran dengan melalui proses analisis yang cermat sehingga pesanan sesuai dengan kebutuhan, baik jenis, jumlah maupun mutunya.

Permasalahan ini dapat diatasi dengan mengikuti pelatihan yang diselenggarakan pemerintah sehingga petani mendapat pengetahuan dalam meningkatkan produksi buah dan penanganan masa panen yang dapat menghasilkan buah dalam kualitas terbaik, petani buah juga disarankan membentuk kumpulan kelompok tani untuk memenuhi ketersediaan/ kontinuitas buah yang diperlukan oleh industri pariwisata. Kontinuitas buah lokal berdampak pada mempromosikan buah lokal dibandingkan buah impor. Promosi buah lokal disajikan dalam olahan makanan dan minuman sehingga dapat menarik minat wisatawan yang menginap untuk mencicipinya.

Penyajian buah lokal pada setiap hotel sebaiknya mempunyai peraturan yang tertulis mengenai pemanfaatan buah lokal dari segi standard dan kualitas buah lokal yang dimanfaatkan untuk operasional. Pemanfaatan buah lokal yang diserap oleh hotel diharapkan kerjasama dengan pemerintah dengan mengadakan pelatihan atau seminar untuk petani buah, mengadakan sidak tentang kualitas buah ke kelompok tani, membantu modal petani dalam mengembangkan buah lokal dan lebih memaksimalkan penerapan Peraturan Daerah Provinsi Bali tentang perlindungan buah lokal untuk meminimalkan beredarnya buah impor.

\section{Ucapan Terima Kasih}

Pertama-tama perkenankanlah penulis memanjatkan puji syukur ke hadapan Ida Sang Hyang Widhi Wasa/ Tuhan Yang Maha Esa, karena hanya atas asung wara nugraha-Nya/karunia-Nya, artikel ini dapat diselesaikan. Pada kesempatan ini perkenankanlah penulis megucapkan terima kasih yang sebesar-besarnya kepada Pembimbing I yaitu Prof. Dr. Ir. I.G.P. Wirawan, M.Sc. dengan penuh perhatian telah memberikan dorongan, semangat, bimbingan dan saran selama penulis mengikuti program Magister Kajian Pariwisata, khususnya dalam penyelesaian tesis ini. Terima kasih sebesar-besarnya pula penulis sampaikan kepada Dr. I Nyoman Madiun, 
M.Sc., Pembimbing II yang dengan penuh perhatian dan kesabaran telah memberikan bimbingan dan saran kepada penulis. Tidak lupa penulis ucapkan terima kasih kepada Prof. Dr. I Nyoman Darma Putra, M.Litt, Ketua Program Studi Magister Kajian Pariwisata atas ijin yang diberikan kepada penulis untuk mengikuti pendidikan Program Magister Kajian Pariwisata dan kepada semua pihak yang telah membantu pelaksanaan dan penyelesaian artikel ini.

\section{Daftar Pustaka}

Antara, Made dan I Gede Yono Wirawan. 2013. Permintaan Buah Pisang Ambon oleh Rumah Tangga di Kecamatan Denpasar Barat, Kota Denpasar, Provinsi Bali dalam Jurnal Ekonomi Kuantitatif Terapan, Februari 2013, Vol 6 No 1, Hal 16-29.

Assauri, Sofjan. 2009. Manajemen Pemasaran. Jakarta: Raja Grafindo Sejahtera.

Riyadi, Heru, Anwari Masatif dan Budi Wibowo. 2011.Pengetahuan Menu. Bandung: Alfabeta.

Suprapti, Wayan Sri. 2010.Perilaku Konsumen (Pemahaman Dasar dan Aplikasi dalam Strategi Pasar). Denpasar: Udayana University Press.

Peraturan Daerah Provinsi Bali No. 3 Tahun 2013, tentang Perlindungan Buah Lokal. Undang-Undang Republik Indonesia No. 10 Tahun 2009, tentang Kepariwisataan.

Wirawan, IGP, Nyoman Wijaya dan Putu Anom. 2014. "Peningkatan Daya Saing Buah Lokal Memasuki Pasar Pariwisata Bali” dalam Laporan Penelitian MP3EI 2014, Jurnal ICBB, September 2014, Vol 2 No. 1, Hal 20-25.

\section{Profil Penulis}

I Gusti Agung Diah Adelianie, SST.Par adalah mahasiswa Magister Kajian Pariwisata di Universitas Udayana Angkatan 2013. Ia menyelesaikan program studi Diploma IV dengan mengikuti Program Lintas Jenjang perkuliahan dari Diploma III Jurusan Pariwisata ke Manajemen Bisnis Pariwisata di Politeknik Negeri Bali. Pengalaman yang dimiliki di bidang pariwisata adalah terakhir bekerja pada sebuah hotel berbintang di kawasan Sanur sebagai Food and Beverages Secretary. 